\title{
Cage culture of Oreochromis Mossambicus (Tilapia) in back water of river Godavari, Nanded, Maharashtra India
}

\begin{abstract}
Cage culture practice is an important technology for culture of finfish and non fin fish organisms. It is gaining importance day by day. This was a first attempt to check the suitability of cage culture in back water of Godavari. This water remains present up to March and April; hence this experiment was carried out from October 2012 to April 2013 (180 days) at Dhangar Takli on the bank of river Godavari. Results showed that Oreochromis mossambicus fish was useful fish for cage culture practice in this area. Although, the Monosex culture of Oreochromis mossambicus may be more applicable because this fish is prolific breeder. If we alter the breeding of fish then this will may help to increase the growth of the fish. Oreochromis mossambicus commonly called as freshwater pomfret. People of this area consume this fish is in high quantity; hence for high production this cage culture method may be helpful.
\end{abstract}

Volume 4 Issue $3-2019$

\author{
Jayvardhan V Balkhande \\ Department of Zoology, Digambarrao Bindu ACS College \\ Bhokar Dist Nanded, India \\ Correspondence: Dr. Jayvardhan V Balkhande, Assistant \\ Professor, Department of Zoology, Digambarrao Bindu ACS \\ College, Bhokar Dist. Nanded, Maharashtra, 43I80I India, Tel \\ 9730159445, 8055250827, Email cageculture2014@gmail.com
}

Received: April 24, 2019 | Published: May 07, 2019

Keywords: cage culture, Godavari, tilapia, backwater, Oreochromis Mossambicus

\section{Introduction}

Culture of fresh water fishes in square or round boxes along with artificial feeding, management for the more production is called cage culture. This practice is suitable for the backwater because the water is present throughout the year, as this water is reserved for drinking, irrigation purpose. Fishermen of that particular area may use this water for culture fishery. This technology is helpful to focus on culture fisheries, in the region of Marathwada fishermen busy in only capture fishery. If we done only capture fishery then the fish resources get decline day by day. Fish production in cages became highly popular among the small or limited resource farmers who are looking for alternatives to traditional agricultural crops. Cage culture is advantageous for farmers as it offers a chance to maximum utilization of existing water resources. Therefore, the farmers do not have to invest on accumulating water. Cage aquaculture has certain advantages over other aquaculture systems that are potentially important in terms of uptake by rural poor and landless people. ${ }^{1}$ Production of fish from Inland capture fisheries is on declining trend in the last few years because of several man made activities like, habitat destruction, pollution, climate change etc. hence reservoir needs immediate attention for development of fisheries in a scientific and sustainable manner to augment the fish production for the population of India. ${ }^{2}$

The Cage culture practice is important to the landless people as they can use communal water bodies for the culture of fishes in cages. It is better way to obtain nutrition and income from the fish production. This method is also useful to eradicate the common problem i.e. multiple ownership. Anyone can use this technology, ownership is easy, means the owners of the cages are the real proprietor of the cage. Fishes which are culture in the cages are not escaping from the net, it also provide feeding ring at the top for feeding purpose. It is also useful to protect the culture fishes from the other predatory fishes. Harvesting mechanism is simple and easy as compare to capture fishery. This will also helps to conservation of endangered fishes. When the fishermen release the fingerlings to any pond, the mortality is the big issue. By using this technology, we can reduce the percentage of mortality in fingerlings. We can save them from predatory fishes that are already present in water body, if we culture in cages the problem of predatory fishes is solved. The management of fishes is easily done in cage culture practice.

This study was carried out for the first time in Marathwada region of Maharashtra state. The experiment was undertaken to check the suitability of Oreochromis mossambicus in cage culture in the backwater of river Godavari. Oreochromis mossambicus, Tilapia has good potential for the enhancement of production in the fishery sector of India but considerable research is required to adopt different techniques of tilapia culture that are practiced in other countries. The fish is actually cultured in diverse systems in inland rural areas, in areas around large cities, in wastewater ponds and even in brackish water ponds in coastal areas. The advantages of such culture are widely recognized for rural food supply. It can provide an opportunity to balance the use of supplementary feeding in correlation with the natural food availability and hence reduce the production cost. Semiintensive and intensive cage cultures are also viable in a range of circumstances. The management flexibility of close culture systems can be achieved in open water through such cage culture method. ${ }^{3}$

\section{Advantage of cage culture}

The rearing and raising of fishes in cages is gaining importance all over the world because of its increasing technical, ecological, social and economic advantages over capture fisheries and conventional aquaculture.

\section{Advantages of cage culture in Marathwada are as follows:}

a. Back water of rivers present in Marathwada can be used for cage culture practice.

b. This method of culture is useful to poor and needy person who are lives near to shore the river.

c. If proper artificial feeding is done then the chances of high production from cage culture is more. 
d. Management of fishes is very easy.

e. We can culture more than one crop in a year, this cannot possible in pond, reservoirs etc.

f. If we culture Monosex of tilapia then the continuous breeding will stop and more growth will observe

g. We can check the proper feeding mechanism in cage culture technology which cannot possible in pond or any other culture system because of vast area of water body.

h. The cages were use again and again by using some minor repairing so the investment is also few.

i. The locally available material may be used for the construction of cages and it will help to the fishermen community to employment.

j. So cage culture technology not only helpful to culture of fishes but also by constructing the cages gives double income to the fishermen.

By considering the importance of Cage culture, this experiment was set up for the first time in Marathwada region because in this area plenty of water resources are available, that can be useful for this technology. If this cage culture technology will spread among the fishermen, fish farmers and entrepreneur related with fishery sector then this will helpful for increasing their income. Hence this work was carried out to check the suitability of Oreochromis mossambicus in cage culture from October 2012 to April 2013 at Dhangar Takli, a village situated on river Godavari.

\section{Materials and methods}

The back water of river Godavari is spread up to 40KM from Vishnupuri Project, Dhangar Takli situated on bank of river Godavari $19^{\circ} 7^{\prime} 12^{\prime \prime} \mathrm{N} 77^{\circ} 3$ '2 $28^{\prime \prime} \mathrm{E}$ was selected as a study area.

\section{Fabrication of cages}

For the experiment fabrication of cages was important hence cages were fabricated from strong, durable, and non-toxic iron material with suitable size mesh. This material was easily available in any local market.

\section{Cage materials}

The 6' X 4' X 4' sized cages were used for the experiment. They were kept in submerged condition as the back water level decreases day by day because the farmers of this area used this water for their farm. The good qualities of iron square pipes were used for the frame. The frames of cages were prepared by gas welding. . The small mesh size was selected for easy circulation of water and to avoiding the escape of fingerlings from the cages. For the artificial feeding and management of fishes a feeding ring was prepared on the top of cages.

The cages were constructed by using the mesh to all sides except the bottom, by using the binding wire the mesh sheet was fixed to the frame. The galvanized sheet was used to the bottom of cages. Painting was done by using red oxide and sky blue oil paint.

Oreochromis mossambicus (Fresh water Pomfret)-Bottom feeder and Omnivorous fish was elected for the experiment.

\section{Stocking of fish}

Fingerlings of Oreochromis mossambicus collected from Mr. Parbatkumar Fish farmer from Ahmadpur, Dist. Latur. Fingerlings were conditioned and brought in oxygenated polythene bag. Before stocking, length and weight of individual fish was measured and kept in different sets, one set with artificial food and second set was without artificial food i.e. with natural food. The stocking density was 100 fingerling/72 cubic foot.

\section{Feeding}

Fish was fed with commercial pelleted feed brought from Krishi Vigyan Kendra, Karda Tq. Risod Dist. Washim, as per their body weight i. e. $5 \%$ of their body weight, in the morning hours at 7:00 am every day.

\section{Cage management}

Cage management is one of the most important tasks in cage culture. Hence cages were cleaned regularly before feeding, to remove dead fishes, uneaten food etc. to keep the environment good for fish. The cages were lifted partially from water every 8 days before feeding, to check the damage and remove algal blooms.

\section{Culture period}

Fingerling of Oreochromis mossambicus was cultured in cages for 180 days.

\section{Water quality parameters}

Water is the most vital resource for all kinds of life on this planet. This resource is adversely affected qualitatively and quantitatively by human activities. ${ }^{4}$ During the study important limnological parameters such as Temperature, $\mathrm{pH}$, Transparency, Total alkalinity, Dissolved Oxygen (DO), Free Carbon dioxide $\left(\mathrm{CO}_{2}\right)$, Chloride, Hardness, Calcium, Magnesium, and Productivity were analyzed by using standard method as suggested in. ${ }^{5}$

\section{Statistical analysis}

The data were expressed in terms of mean \pm standard error. All data were subjected to one-way ANOVA. This analysis was done by using Graph pad Prism Software 6.

\section{Organization of workshop}

The cage culture technology is not known in this area; hence for popularization one day workshop was organized for the fish farmers, businessman, teacher's researchers and students so that activity of fish culture will spread.

\section{Results}

The growth performance of Oreochromis mossambicus, in natural and artificial feeding cages in terms of final weight, weight gain percentage, specific growth rate (SGR \%), Daily growth rate (DGR), survival rate ,total production and physico chemical parameters were shown in table No.1,2 and 3.

\section{Mean weight}

The mean initial length of Oreochromis mossambicus for I, II, III, IV, V and VI th months was $0.7,4.0,6.4,8.4,10.9$ and $13.7 \mathrm{~cm}$ respectively. Their mean final length was $4.0 \pm 0.38,6.4 \pm 0.31,8.4 \pm 0.28$, $10.9 \pm 0.51,13.7 \pm 0.65$ and $15.8 \pm 0.56 \mathrm{~cm}$ for six months respectively. The mean final weight of natural feed cage was $3.83 \pm 0.47,6.20 \pm 0.35$, $8.86 \pm 0.94,15.69 \pm 1.48,37.40 \pm 7.21$ and $64.65 \pm 8.32 \mathrm{gm}$ for I, II, III, IV, $\mathrm{V}$ and VI the months respectively. 
In artificial feeding cage, the mean initial length was $0.8,5.7,7.2$, $9.4,12.5$ and $14.8 \mathrm{~cm}$, their mean final length was $5.7 \pm 0.45,7.2 \pm 0.41$, $9.4 \pm 0.67,12.5 \pm 0.59,14.8 \pm 0.51$ and $19.3 \pm 0.80 \mathrm{~cm}$ in I, II, III, IV, $\mathrm{V}$ and VI th months respectively. Their final weight was6.06 \pm 1.54 , $7.60 \pm 1.53,13.07 \pm 2.35,24.13 \pm 3.17,69.38 \pm 9.48$ and $148.84 \pm 10.31 \mathrm{gm}$ recorded in I, II, III, IV, V and VI the months respectively. The mean weight of natural feeding cage was $64.65 \pm 8.32 \mathrm{gm}$ and in artificial feeding cage, Oreochromis mossambicus attained $148.84 \pm 10.31 \mathrm{gm}$.

\section{Weight gain \%}

The weight gain percentage of Oreochromis mossambicus was $155.3,61.87,42.90,77.08,138.3$ and $72.86 \%$ in natural feeding cage. In artificial feeding cage the percentage of weight gain was 304 $25.41,71.97,84.62,187.5$ and $114.5 \%$ in I, II, III, IV, V and VI th months respectively.

\section{Specific growth rates (SGR)}

The specific growth rates (SGR) with treatments are given in Table 1 and Table 2. The treatments without artificial feeding attained the least mean SGR7.7\%/day/fish, 7.9\%/day/fish, 8.8\%/day/fish, 22.76\%/ day/fish, $72.36 \% /$ day/fish and $90.83 \% /$ day/fish, respectively.

In artificial feeding cage mean SGR 15.2\%/day/fish, 5.13\%/day/ fish, $18.23 \%$ /day/fish, 36.86\%/day/fish, $150.8 \%$ /day/fish and $264.8 \%$ / day/fish.

Table I Depicts the Growth analysis of I00 fingerling of Oreochromis mossambicus in natural feeding from October 2012 to April 20 I 3 at Dhangar Takli (I80 days)

\begin{tabular}{llllllllll}
\hline Months & $\begin{array}{l}\text { Initial length } \\
(\mathbf{c m})\end{array}$ & $\begin{array}{l}\text { Final } \\
\text { length }(\mathbf{c m})\end{array}$ & $\begin{array}{l}\text { Initial weight } \\
(\mathbf{g m})\end{array}$ & $\begin{array}{l}\text { Final weight } \\
(\mathbf{g m})\end{array}$ & WG \% & SGR & DGR & Mortality & Survival \% \\
\hline Oct-12 & 0.7 & & 1.5 & & & & & 19 & 81 \\
Nov-12 & 0.7 & $4.0 \pm 0.38$ & 1.5 & $3.83 \pm 0.47$ & 155.3 & 7.7 & 0.07 & 0 & 81 \\
Dec-12 & 4 & $6.4 \pm 0.31$ & 3.83 & $6.20 \pm 0.35$ & 61.87 & 7.9 & 0.07 & 1 & 80 \\
Jan-13 & 6.4 & $8.4 \pm 0.28$ & 6.2 & $8.86 \pm 0.94$ & 42.9 & 8.8 & 0.08 & 0 & 80 \\
Feb-13 & 8.4 & $10.9 \pm 0.51$ & 8.86 & $15.69 \pm 1.48$ & 77.08 & 22.76 & 0.22 & 0 & 80 \\
Mar-13 & 10.9 & $13.7 \pm 0.65$ & 15.69 & $37.40 \pm 7.21$ & 138.3 & 72.36 & 0.72 & 0 & 80 \\
Apr-13 & 13.7 & $15.8 \pm 0.56$ & 37.4 & $64.65 \pm 8.32$ & 72.86 & 90.83 & 0.9 & 0 & 80 \\
& & & Total fish production(kg) =5.1kg & & & & &
\end{tabular}

'WG \%,Weight gain percentage; 2SGR, Specific growth rate; 3DGR, Daily growth rate

Table 2 Depicts the Growth analysis of 100 fingerling of Oreochromis mossambicus in artificial feeding from October 2012 to April 2013 at Dhangar Takli (I80 days)

\begin{tabular}{llllllllll}
\hline Months & $\begin{array}{l}\text { Initial } \\
\text { length }(\mathbf{c m})\end{array}$ & $\begin{array}{l}\text { Final length } \\
(\mathbf{c m})\end{array}$ & $\begin{array}{l}\text { Initial } \\
\text { weight }(\mathbf{g m})\end{array}$ & $\begin{array}{l}\text { Final weight } \\
(\mathbf{g m})\end{array}$ & WG \% & SGR & DGR & Mortality & Survival \% \\
\hline Oct-12 & 0.8 & & 1.5 & & & & & 24 & 76 \\
Nov-12 & 0.8 & $5.7 \pm 0.45$ & 1.5 & $6.06 \pm 1.54$ & 304 & 15.2 & 0.15 & 0 & 76 \\
Dec-12 & 5.7 & $7.2 \pm 0.41$ & 6.06 & $7.60 \pm 1.53$ & 25.41 & 5.13 & 0.05 & 0 & 76 \\
Jan-13 & 7.2 & $9.4 \pm 0.67$ & 7.6 & $13.07 \pm 2.35$ & 71.97 & 18.23 & 0.18 & 0 & 76 \\
Feb-13 & 9.4 & $12.5 \pm 0.59$ & 13.07 & $24.13 \pm 3.17$ & 84.62 & 36.86 & 0.36 & 0 & 76 \\
Mar-13 & 12.5 & $14.8 \pm 0.51$ & 24.13 & $69.38 \pm 9.48$ & 187.5 & 150.8 & 1.5 & 0 & 76 \\
Apr-13 & 14.8 & $19.3 \pm 0.80$ & 69.38 & $\mid 148.84 \pm 10.31$ & 114.5 & 264.8 & 2.6 & 0 & 76 \\
& & & Total fish production $(\mathrm{kg})=11.3 \mathrm{~kg}$ & & & & & & \\
\hline
\end{tabular}

IWG \%,Weight gain percentage; 2SGR, Specific growth rate; 3DGR, Daily growth rate

The fish attained the maximum mean SGR $264.8 \%$ /day/fish and the minimum mean SGR 5.13\%/day/fish among the artificial feeding cage.

\section{Daily growth rates (DGR)}

Mean daily growth rate of Oreochromis mossambicus was calculated between natural feeding cage and supplementary cage. The mean daily growth rate of $0.07 \mathrm{~g} / \mathrm{day}, 0.07 \mathrm{~g} / \mathrm{day}, 0.08 \mathrm{~g} /$ day, $0.22 \mathrm{~g} /$ day, $0.0 .72 \mathrm{~g} /$ day and $0.90 \mathrm{~g} /$ day were recorded in natural feeding cage.

A mean daily growth rate of $0.15 \mathrm{~g} /$ day, $0.05 \mathrm{~g} /$ day, $0.18 \mathrm{~g} /$ day, $0.36 \mathrm{~g} / \mathrm{day}, 1.5 \mathrm{~g} /$ day and $2.6 \mathrm{~g} /$ day was recorded in the feeding cage. In supplementary feeding cage daily growth rate was higher than natural feeding.

\section{Survival \%}

Survival rate was $80 \%$ for natural feeding cage, whereas it was $76 \%$ recorded in Supplementary feeding cage during the culturing period.

\section{Yield/total production}

The total weight gained (yield) for each treatment per cage is depicted in Table 1 and Table 2 . The weight increased was significantly 
different with and without artificial feeding experiments. The total fish production of Oreochromis mossambicus in 180 days was more in artificial feeding cage as compare to natural feeding cage. $11.3 \mathrm{~kg}$ recorded in artificial feeding cage and only $5.1 \mathrm{~kg}$ recorded in natural feeding cage.

In study of Oreochromis mossambicus the t test Welch's correction for length was described in Figure 1 Welch' corrected t was 31.09 and $\mathrm{df}=133.2$ and these results are significant. This calculation was carried out in $95 \%$ confidence interval i. e. 3.264 to 3.708 . According to $t$ test Welch's correction the length of Oreochromis mossambicus in natural feed caged fishes and artificial feed caged fishes were significant. F test was also carried out for compare variances and the values are $\mathrm{F}=2.064$, $\mathrm{Dfn}=75$ and $\mathrm{Dfd}=79$ obtained. The $\mathrm{p}$ value for this data is 0.0017 and this study shows significant difference.

\begin{tabular}{|l|l|}
\hline Table Analyzed & One-way ANOVA data \\
\hline Column B & Artificial Feed \\
\hline vs. & vs. \\
\hline Column A & Natural Feed \\
\hline & \\
\hline Unpaired t test with Welch's correction & \\
\hline P value & $<0.0001$ \\
\hline P value summary & $\star \star * *$ \\
\hline Significantly different? $(\mathrm{P}<0.05)$ & Yes \\
\hline One- or two-tailed $P$ value? & Two-tailed \\
\hline Welch-corrected $t$, df & $\mathrm{t}=31.09 \mathrm{df}=133.2$ \\
\hline & \\
\hline How big is the difference? & \\
\hline Mean \pm SEM of column $\mathrm{A}$ & $15.88 \pm 0.06295, \mathrm{n}=80$ \\
\hline Mean \pm SEM of column $\mathrm{B}$ & $19.37 \pm 0.09278, \mathrm{n}=76$ \\
\hline Difference between means & $3.486 \pm 0.1121$ \\
\hline 95\% confidence interval & 3.264 to 3.708 \\
\hline R squared & 0.8789 \\
\hline & \\
\hline F test to compare variances & \\
\hline F,DFn, Dfd & $2.064,75,79$ \\
\hline P value & 0.0017 \\
\hline $\mathrm{P}$ value summary & $\star * *$ \\
\hline Significantly different? $(\mathrm{P}<0.05)$ & Yes \\
\hline
\end{tabular}

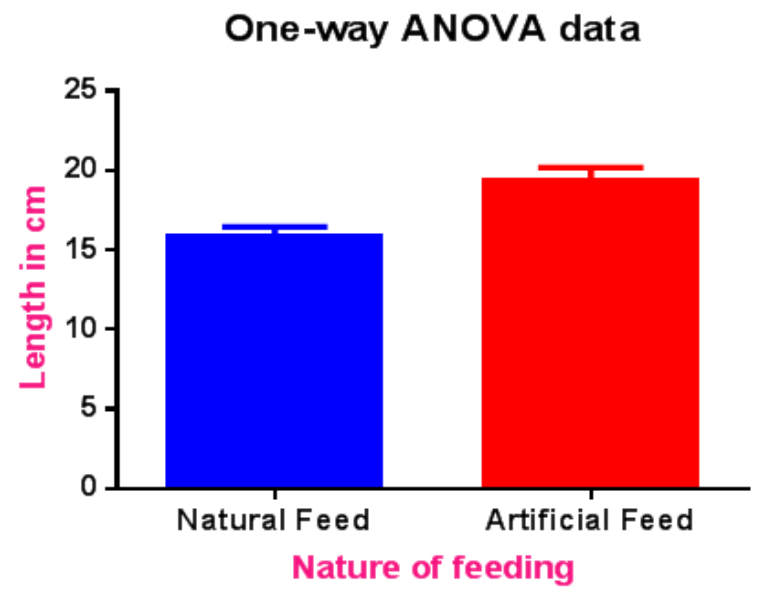

Figure I $\mathrm{t}$ test with Welch's correction for Length of Oreochromis Mossambicus (Cage culture).
The $\mathrm{t}$ test Welch's correction for weight for Oreochromis mossambicus was described in Figure 2. $\mathrm{t}=55.93$ and $\mathrm{df}=144.2$ obtained hence according to $t$ test Welch's correction this result is significantly different i.e. $\mathrm{P}<0.05$. But these results are not significantly different for $F$ test. When it is compared with variances, the $p$ value is 0.0616 .

\begin{tabular}{|l|l|}
\hline Table Analyzed & One-way ANOVA data \\
\hline & \\
\hline Column B & Artificial Feed \\
\hline vs. & Vs. \\
\hline Column A & Natural Feed \\
\hline & \\
\hline Unpaired t test with Welch's correction & \\
\hline $\mathrm{P}$ value & $<0.0001$ \\
\hline P value summary & $* \star * *$ \\
\hline Significantly different? $(\mathrm{P}<0.05)$ & Yes \\
\hline One- or two-tailed $\mathrm{P}$ value? & Two-tailed \\
\hline Welch-corrected t, df & $\mathrm{t}=55.93 \mathrm{df}=144.2$ \\
\hline & \\
\hline How big is the difference? & \\
\hline Mean \pm SEM of column $\mathrm{A}$ & $64.66 \pm 0.9308, \mathrm{n}=80$ \\
\hline Mean \pm SEM of column B & $148.8 \pm 1.183, \mathrm{n}=76$ \\
\hline Difference between means & $84.19 \pm 1.505$ \\
\hline $95 \%$ confidence interval & 81.21 to 87.16 \\
\hline R squared & 0.9560 \\
\hline & \\
\hline F test to compare variances & \\
\hline F,DFn, Dfd & $1.534,75,79$ \\
\hline $\mathrm{P}$ value & 0.0616 \\
\hline $\mathrm{P}$ value summary & $\mathrm{ns}$ \\
\hline Significantly different? $(\mathrm{P}<0.05)$ & $\mathrm{No}$ \\
\hline &
\end{tabular}

\section{One-way ANOVA data}

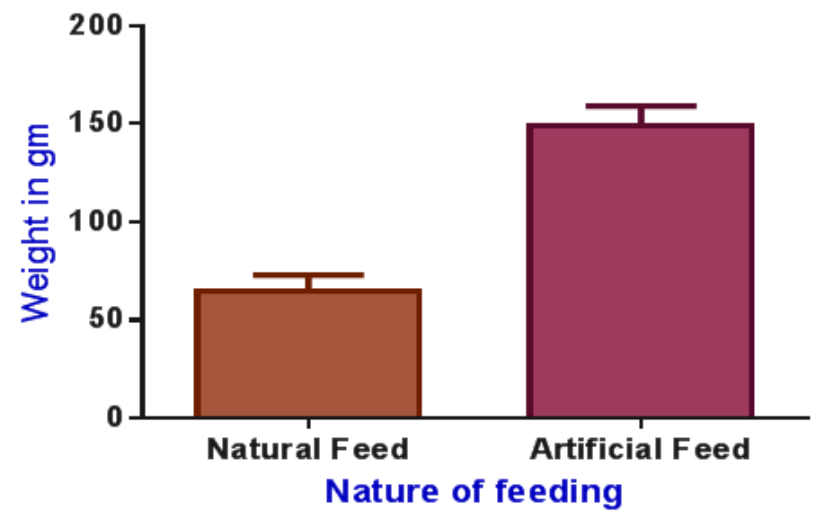

Figure $2 \mathrm{t}$ test with Welch's correction for Weight of Oreochromis Mossambicus (Cage culture).

The one day workshop was organized to introduce the idea of fish culture in cages among the fish farmers, businessman, teacher's researchers and students so that activity of fish culture will increase. That would also contribute to countering of the ongoing declining trend in capture fisheries. This will help for addition of another chapter "BLUE" revolution in Marathwada. This workshop was organized on 06/09/2013 with collaboration with College of Fishery Science, Tq. Udgir Dist. Latur. (MAFSU, Nagpur) (Table 3). 
Table 3 Physico chemical parameters of river Godavari at Dhangar Takli from July 20I2-April 2013.

\begin{tabular}{|c|c|c|c|c|c|c|c|c|c|c|c|}
\hline \multirow{2}{*}{ Months } & \multirow{2}{*}{$\mathrm{pH}$} & \multicolumn{2}{|c|}{$\begin{array}{l}\text { Temperature } \\
\left({ }^{\circ} \mathrm{C}\right)\end{array}$} & \multirow{2}{*}{$\begin{array}{l}\text { Transparency } \\
(\mathrm{cm})\end{array}$} & \multirow{2}{*}{$\begin{array}{l}\text { DO } \\
\text { mg/L }\end{array}$} & \multirow{2}{*}{$\begin{array}{l}\mathrm{CO}_{2} \\
\mathrm{mg} / \mathrm{L}\end{array}$} & \multirow{2}{*}{$\begin{array}{l}\text { Chloride } \\
\mathrm{mg} / \mathrm{L}\end{array}$} & \multirow{2}{*}{$\begin{array}{l}\text { Alkalinity } \\
\mathrm{mg} / \mathrm{L}\end{array}$} & \multirow{2}{*}{$\begin{array}{l}\text { Hardness } \\
\text { mg/L }\end{array}$} & \multirow{2}{*}{$\begin{array}{l}\text { Calcium } \\
\mathrm{mg} / \mathrm{L}\end{array}$} & \multirow{2}{*}{$\begin{array}{l}\text { Magnesium } \\
\text { mg/L }\end{array}$} \\
\hline & & Air & Water & & & & & & & & \\
\hline July & 7.4 & 30 & 28 & 5.5 & 8.5 & 3 & 52.54 & 480 & 190 & 31.26 & 13.15 \\
\hline August & 7.7 & 29 & 28 & 5 & 8.16 & 3.6 & 34.08 & 410 & 164 & 31.26 & 12.18 \\
\hline September & 8 & 28 & 27 & 19.5 & 7.7 & 4.4 & 39.76 & 440 & 172 & 35.27 & 14.13 \\
\hline October & 7.8 & 26 & 25 & 35.5 & 6.7 & 0.4 & 35.5 & 240 & 136 & 36.87 & 16.08 \\
\hline November & 7.4 & 29 & 28 & 39.5 & 5.71 & 0.8 & 39.76 & 250 & 132 & 17.63 & $|4.6|$ \\
\hline December & 7.6 & 20 & 19 & 41.5 & 5.1 & 0.4 & 28.4 & 270 & 142 & 20.04 & 16.08 \\
\hline January & 7.4 & 19 & 18 & 39.5 & 7.5 & Nil & 38.34 & 320 & 116 & 24.84 & 16.56 \\
\hline February & 7.2 & 17 & 18 & 34.5 & 5.3 & Nil & 35.5 & 250 & 124 & 23.24 & 20.95 \\
\hline March & 7.8 & 32 & 31 & 46.5 & 7.7 & 0.6 & 46.86 & 230 & 110 & 25.65 & 33.66 \\
\hline April & 7.3 & 34 & 32 & 41.5 & 5.51 & Nil & 51.12 & 270 & 94 & 30.46 & 39.27 \\
\hline SD & \pm 0.25 & \pm 5.79 & \pm 5.25 & \pm 15.26 & \pm 1.28 & \pm 1.67 & \pm 7.75 & \pm 92.64 & \pm 29.79 & \pm 6.38 & \pm 9.28 \\
\hline
\end{tabular}

\section{Discussion}

${ }^{6}$ conducted study on The Potential of Phytoplankton-based culture of Tilapia (Oreochromis niloticus) in floating cages in Seyhan Dam Lake. Their study showed that the growth performance of Tilapia reared in extensive condition is lower than that of intensive and semiintensive culture conditions. However, when cost of production is considered, extensive cage culture of Tilapia could be an alternative among the other culture models.

Our result showed that the growth of supplementary feed supplied to Oreochromis mossambicus was more than the natural feed fish cage. Similar type of work was done by ${ }^{7}$ they found that growth of Clarias batrachus (Linnaeus) was more with selected non-conventional diets in a floodplain wetland of Assam in Cage culture.

${ }^{8}$ studied the effects of stocking density $(50,100,150$ and 200fish/ $\mathrm{m}^{3}$ cages) for the Nile tilapia [Oreochromis niloticus (L.1758)] and found that the fish size and production were significantly affected by stocking density. They had done their experiments on stocking densities and feed quantity of different lakes and reservoir. They had also mentioned that supplementary feed increases the growth performance of $O$. niloticus without harming the water quality.

${ }^{3}$ Explained the different Traditional and Non-Traditional Methods for Culture of Monosex Nile Tilapia in India. ${ }^{9}$ had done research on Determination of Ideal Stocking Density for Cage Culture of Monosex Nile Tilapia (Oreochromis Niloticus) in India and found that the highest growth was observed for the $50 \mathrm{fish} / \mathrm{m}^{3}$ groups for both the control and hormone treated categories. ${ }^{10}$ Reported that the quantity of the feed given to the stock depends on the utilization and it works to 3 to $5 \%$ body weight of the cage reared air breathing fishes; in our study we also provide the artificial feed to the caged fish as per $5 \%$ of their body weight.

Some researchers were work on Cage culture by using different species of fishes such as ${ }^{11}$ fed the Epinephelus malabaricus (Bloch and Scheneider, 1801) in Mandapam Coastal waters (Southeast Coast of India) in cage culture with different diets all at a rate of 250 to
$350 \mathrm{~g}$ fish receive $5 \%$ body weight daily, 350 to $500 \mathrm{~g}$ receive $3 \%$ body weight daily 500 to $600 \mathrm{~g}$. In the present study the fishes fed with artificial pelleted feed with $5 \%$ body weight daily. ${ }^{12}$ showed the effect of stocking density on yield, growth, and survival of Asian river catfish (Pangasius bocourti Sauvage, 1880) cultured in cages. The Asian river catfish, Pangasius bocourti cultured in small cages placed in a pond reached the desirable market size $(200 \mathrm{~g})$ within a 90-day grow-out period. These studies were similar with our findings. Experiment on Catla catla, Labeo rohita, Cyprinus carpio, Tor pititora and Tor Khudree was carried out by, ${ }^{13}$ they suggested cage culture is feasible for raising fingerlings. They observed that cage culture technique for rearing of seed should be taken up as a fish enhancement programme in which true economic gains will be reflected only when the production of the reservoir is increased. ${ }^{14}$ Another work was carried out in Madhya Pradesh on cage culture, the survival \% of Catla catla was $58.9 \%$ and $78.7 \%$ whereas it was $63.3 \%, 57.3 \%$ and $74.2 \%$ in cages culture. Similar findings were observed in our study. An interesting study was carried out by ${ }^{15}$ on Cage Culturing the Endangered Bonytail, in Arizona. U. S. A. The Bonytail Gila elegans was the most endangered of endemic Colorado River fishes primarily because of habitat loss and predation by introduced fishes. Results of this study suggested that stocking juvenile bonytails in cages at approximately $18-22 \mathrm{fish} / \mathrm{m}^{3}$ and using individuals representing a wide range of body sizes would maximize growth and survivorship. Hence we can use this technique for the culture of endangered fishes also. Similar type of study had been carried out by ${ }^{16}$ at same place for Catla catla fish; it was observed that Catla catla fish also suitable for cage culture in back water of river Godavari. Author was worked on Catla catla, important Indian major carp, they showed that this species was also cultivable fish in back water.

\section{Conclusion}

The study was concluded that Oreochromis mossambicus fish was suitable for cage culture practice in Marathwada region. Artificial feeding is needed to improvement in the total production.

It was found that, all the physico- chemical parameters were 
admissible limit for cage culture of Oreochromis mossambicus. Although this fish was prolific breeder, it was recommended that instead of culturing both sexes in a cage, the Monosex culture was more suitable for the growth of the fish.

Rearing of this Oreochromis mossambicus through cage culture may be useful method to increase the fish production. India stands second position in population hence for fulfill the demand of people cage culture is most needed intensively in order to meet the future food demands and also to improve the aquaculture business in Marathwada region. More experiments should be arranged on cage culture by taking another important fishes for the culture in cages.

Demand of cheapest protein in the form of fish is increases day by day and we are still depending on capture fisheries. The stock is not sufficient to this enormous population hence by accepting the culture technique such as cage culture is considered as the important and need of the day to increase the fish production. The Cage culture technique is not spread yet in this area; hence more workshops should be arranged for the popularization of the cage culture. Successful cage culture practice is helpful to the fish farmers, fishermen and other entrepreneur who are direct related to the fish business. This technique is also helpful for the development of rural communities, if proper support in the form of training was provided to them. It helps them to generate employment opportunity and improvement of livelihood. The role of women in Cage culture is very important as they can play a crucial role in both in both culturing and selling of fresh fishes or manufacturing of various value added products of fishes Nowadays in Marathwada "Mahila Bachat Gat" actively work on various issues for improvement of their socio- economic status.

\section{Acknowledgments}

The author is thankful to UGC (SA) New Delhi for Award of Rajiv Gandhi National Fellowship for carry out this research work. Author is thankful to Dr. A. N. Kulkarni Rtd. Head for whole hearted support and encouragement during the work. Author is also thankful to Principal, N.E.S. Science College, Nanded for providing facilities $\&$ continuous encouragement during study.

\section{Conflicts of interest}

The authors declared no potential conflicts of interest with respect to the research, authorship, and/or publication of this article.

\section{References}

1. Bulcock P, Ken McAndrew. Planning and extension guidelines for smallscale cage aquaculture in Asia. Aquaculture News. 2001:1-3.

2. Fishing Chimes. On promotion of Cage Aqua farming in India. Connect Journals. 2008;28(9):7-8.

3. Chakraborty SB, Samir B. Culture of Monosex Nile Tilapia under Different Traditional and Non-Traditional Methods in India. World Journal of Fish and Marine Sciences. 2009;1(3):212-217.
4. Trivedy RK, Goel PK. Chemical and Biological methods for Water Pollution studies. Karad: Environmental Publication; 1986. 250 p.

5. APHA (American Public Health Association manual). Standard methods for examination of water and waste management. 15th edn. Washington 2000 DC, USA: AWWA-APCF; 2005.

6. Dikel Suat, Gula Kiris, Vedat Alev M. The potential of phytoplanktonbased culture of tilapia (Oreochromis Niloticus) in floating cages in Seyhan Dam Lake. The 7th Balkan Conference on Operational Research BACOR 05, Romania: Constanta; 2005:1-7.

7. Borthakur Sushanta, Umesh C Goswami. Cage culture of magur Clarias batrachus (Linnaeus) with selected non-conventional diets in a floodplain wetland of Assam. Indian J Fish. 2007;54(4):357-363.

8. Gibtan Ashagrie, Abebe Getahun, Seyoum Mengistou. The effect of stocking density and supplementary feeding on growth performance and yield of Nile tilapia [Oreochromis niloticus (L.1758)] in cage culture in Lake Kuriftu, Ethiopa. Aquaculture Research. 2008;39(13):1450-1460.

9. Chakraborty SB, Debasis Mazumdar, Samir Banerjee. Determination of Ideal Stocking Density for Cage Culture of Monosex Nile Tilapia (Oreochromis niloticus) in India. Proc zool Soc. 2010;63(1):53-59.

10. Murugesan VK, Parameswaran S. Culture of air breathing fishes in cages and Pens. Proceedings of the National Seminar on cage and pen culture. Tuticorin: Fisheries College, Tamil Nadu Agricultural University; 1983:59-62.

11. Badhul Haq MA, Srinivasan M, Vignesh R, et al. Cage culture of Epinephelus malabaricus (Bloch and Scheneider, 1801) in Mandapam Coastal waters (Southeast Coast of India). International Journal of Environmental Sciences. 2011;2(2):491-501.

12. Jiwyam Wirat. The effect of stocking density on yield, growth, and survival of Asian river catfish (Pangasius bocourti Sauvage, 1880) cultured in cages. Aquaculture Int. 2011;19(5):987-997.

13. Kohli MP, Ayyapan S, Langer S, et al. Cage culture of carps, Labeo rohita and Cyprinus carpio at Powai lake, Mumbai, Maharashtra. Applied Fisheries and Aquaculture. 2002;11(2):1-4.

14. Tamot Praveen, Rajeev Mishra, Somdutt. Water quality monitoring of Halali reservoir with reference to Cage aquaculture as a modern tool for obtaining enhanced fish production. Proceedings of Taal2007: The 12 $2^{\text {th }}$ World Lake Conference; 2008:318-324.

15. Sowka Patricia A, Paul E Brunkow. Cage culturing the endangered bonytail. North American Journal of Aquaculture. 1999;61(4):326-330.

16. Jayvardhan V Balkhande, Arvind Kulkarni. A first experiment on cage culture of Catla catla in back water of Shankar Sagar reservoir, Vishnupuri Project Dist. Nanded, Marathwada (Maharashtra). Journal of Innovations in Pharmaceutical and Biological Sciences. 2017;4(4):78-86. 